\title{
New Spanish Draft Regulation on the Mutual Agreement Procedures Concerning Direct Taxation
}

\author{
Dr. Aurora Ribes Ribes ${ }^{1}$
}

\section{Status quo of the mutual agreement procedure}

\section{A. The insufficiency of the current system}

Notwithstanding the wide recognition of the mutual agreement procedure - envisaged in Art. 25 of the OECD Model Tax Convention - as an efficient and flexible instrument in the interpretation, application and development of tax treaties, ${ }^{2}$ this mechanism has been extensively criticized in international tax legal scholarship.

The main inconveniences of the mutual agreement procedure, pointed out both by the commentators ${ }^{3}$ and the international organizations, ${ }^{4}$ in particular by the International Fiscal Association ${ }^{5}$ (IFA), can be summarized as follows:

- The competent authorities have no obligation to reach an agreement but only to communicate with each other and negotiate in order to clarify the dispute. In other words, even though the purpose of the provision is to reach an agreement, a solution to the conflict is not guaranteed because the states are merely required to exercise their best efforts. ${ }^{6}$

- There are no time limits within which a solution is required to be found. This results in delays in the procedure, another important deficiency ${ }^{7}$ of this mechanism. In fact, the settlement of the case may take several years because of differences in language, procedures and legal and accounting systems, as well as the inability of the tax authorities to come to an agreement. ${ }^{8}$

- Concerning the publication of the agreement, the criteria adopted are not homogeneous, which is obviously unsatisfactory; thus, it depends on the discretion of each state whether the decisions derived from this procedure are eventually published.

- The mechanism of the mutual agreement procedure does not oblige revenue authorities to implement the solution (if one is reached). On the contrary, more often than not the implementation of the agreement depends upon the domestic laws of the Contracting Parties, which leads consequently to divergent results in each state.

- Some countries tend to adopt a neutral attitude towards the mutual agreement procedure, i.e. they do not demonstrate any interest in using this dispute resolution mechanism, maybe because of the aforementioned deficiencies.

The fact that the wording of Art. 25 of the United Nations Model (UN MC) and Art. 25 of the United States Model (US MC) - which additionally includes a non-exhaustive list of factual questions on which the revenue authorities are authorized to consult and reach an agreement on - are identical to each other but differ in the wording of the same provision in the OECD MC emphasizes the difficulty in finding an appropriate

\section{Notes}

Tax Law Professor. University of Alicante, Spain.

OECD 1984 Report on Mutual Agreement Procedure, paras. 39 and 40.

J.F. Avery Jones et al., 'The legal nature of the mutual agreement under the OECD Model Convention', British Tax Review 1979, p. 337; C. Palao Taboada, 'El procedimiento amistoso en los convenios para evitar la doble imposición', Hacienda Pública Española 1972, no. 16, p. 327; S.H. Goldberg, 'Competent authority', Bulletin for International Fiscal Documentation 1986, vol. 40, no. 10, p. 433; A.A. Skaar, 'The legal nature of mutual agreements under tax treaties,' Tax Notes International 1992, vol. 26, no. 5, pp. 1441-1450; P. Baker, Double taxation conventions and international tax law, 2nd edn (Sweet \& Maxwell, London, 1994), p. 420; R. Casero Barrón, 'La interpretación en Derecho español de los tratados internacionales para evitar la doble imposición. El papel del Consejo de Estado. Propuesta revitalizante o regeneracionista', Carta Tributaria 1998, no. 288, p. 2; T. How Teck, 'The 'Mutual Agreement Procedure' Article in tax treaties Singapore's perspective', Intertax 2000, no. 5, p. 210; A. Ribes Ribes, 'Compulsory arbitration as a last resort in resolving tax treaty interpretation', European Taxation 2002, vol. 42, no. 9, p. 400.

4 For instance, the International Chamber of Commerce (ICC) has also called for changes to be made to the existing mutual agreement procedure in its Conference on 'The resolution of international tax disputes through arbitration' which took place in Paris on 3 May 2006.

5 See, in particular, IFA, 'Mutual Agreement - Procedure and practice', Cahiers de droit fiscal international, vol. LXVIa (Kluwer Law and Taxation Publishers, Deventer, 1981).

6 As Maxime Chrétien declared, the competent authorities have 'la vie des conventions (...) entre leurs mains unies ou separées'. G. Gest, G. Tixier and J. Kerogues, Droit Fiscal International (Librairies Techniques, Paris, 1979), p. 190.

7 In the same vein, Sivalingam affirms that the maxim 'justice delayed is justice denied' is apparently ignored by the competent authorities in practice. See S. Sivalingam, 'Tax treaties - Do they help?', Asia-Pacific Bulletin 1997, vol. 4, no. 3, p. 116.

8 M.P. Bricker, 'Arbitration procedures in tax treaties. A first Israeli tax treaty includes an arbitration clause - But do such clauses really matter?', Intertax 1998, no. 3, p. 102. 
solution. Neither the Nordic Convention of 1996 nor the Andean Group Model Tax Treaty set out an alternative or complementary measure to supersede the impediments of the traditional mutual agreement procedure.

As stated above, this issue has been the subject of extensive discussion in the literature. The conclusion is that the main reason for difficulty resides in the reluctance of the Contracting States to transfer their power to decide upon the terms of a settlement to a body beyond their control because of the diminution of their fiscal sovereignty that this would imply. In this respect, the OECD Committee on Fiscal Affairs also noted that Art. 25 represents the maximum that member countries are prepared to accept, given that this provision is not yet entirely satisfactory.

\section{B. The improvement of the mutual agreement procedure by the OECD: Report of the Committee on Fiscal Affairs on 30 January 2007}

On 27 July 2004, the OECD Committee on Fiscal Affairs released a Progress Report on its work on improving the resolution of cross-border tax disputes. The Report, entitled 'Improving the process for resolving international tax disputes' (2004 Progress Report), included 31 proposals aimed at improving the mutual agreement procedure.

A number of these proposals were directed at tax administrations. Some of them were intended to ensure greater transparency through the dissemination of individual countries' information with regard to the organization of competent authority functions and the procedures to be followed in mutual agreement cases. As a result of work done on these proposals, such information is now provided through the OECD website, which includes a periodically updated list of 'country profiles on mutual agreement procedure' for both OECD and non-OECD countries.

Concerning other proposals that required additional work, on 1 February 2006, a public discussion draft entitled 'Proposals for improving mechanisms for the resolution of tax treaty disputes' (2006 OECD Draft) was released, which provided the results of that followup work. In particular, it included various draft changes $^{9}$ to the OECD MC, dealing primarily with the addition of an arbitration process to solve disagreements arising in the course of a mutual agreement procedure, as well as a suggestion for developing an online Manual on Effective Mutual Agreement Procedure (MEMAP). The written comments received on the 2006 OECD Draft, together with the opinions held in Tokyo on 13 March 2006 during the public consultation meeting - attended by over 150 participants - have been reflected in a number of modifications to be made to the proposed changes to the OECD MC that are currently contained in the Report 'Improving the resolution of tax treaty disputes' adopted by the Committee on Fiscal Affairs on 30 January 2007 (2007 OECD Report).

As it is worded in the introduction of the 2007 OECD Report, Section A includes the revised version of the proposal to add to the OECD MC an arbitration process to deal with unresolved issues that prevent competent authorities from reaching a mutual agreement. As a consequence of the comments on the interaction between the proposed arbitration process and domestic legal remedies, the Committee has changed its proposal and has decided that the person who makes the arbitration request (or any person affected by the case) will not be required to waive rights to domestic remedies as a condition for requesting arbitration.

Besides, Section B includes a slightly revised version of the changes to the Commentary on Art. 25 that address proposals included in the 2004 Progress Report dealing with various issues that may arise in the course of a mutual agreement procedure. Nevertheless, these changes to the OECD MC embodied in Sections A and $\mathrm{B}$ will not be included in the next update to the Model, which will be published in 2008 .

Finally, Section C deals with the follow-up to the other proposals of the 2004 Progress Report, mainly to the online MEMAP that has been developed in response to a number of proposals of the 2004 Progress Report. This Manual explains the various stages of the mutual agreement procedure, discusses some issues related to that procedure and, where appropriate, describes best practices. It is available at www.oecd.org/ctp/memap and will be updated periodically to reflect new developments. Section $\mathrm{C}$ also includes a reporting framework for mutual agreement procedure cases that the Committee intends to use to collect and make public statistical information on mutual agreement procedure cases.

Focusing on the insufficiency of the mutual agreement procedure, the 2007 OECD Report considers that it can be improved by supplementing it with additional dispute resolution techniques, which can help to resolve issues that have prevented the countries from reaching an agreement. Recourse to these techniques, however, should not constitute an alternative way to solve tax treaty conflicts between states but, on the contrary, are aimed at ensuring an agreed solution to their differences once the mutual agreement procedure has proven unsuccessful. Moreover, these additional techniques can make the mutual agreement procedure itself more effective even in cases where resort to the techniques is not necessary. In this sense, governments will have an incentive to ensure that the mutual agreement procedure is conducted efficiently in order to avoid the necessity of subsequent supplemental procedures. 
The following is a revised version of the proposed new paragraph that was included in the 2006 OECD Draft in order to be added (together with its Commentary and Annex) to Art. 25 of the OECD $\mathrm{MC}$, providing for the arbitration of unresolved issues that prevent competent authorities from reaching an agreement on a mutual agreement procedure case within two years. As commented above, the changes to the paragraph reflect the decision not to require a waiver of domestic remedies as a condition for initiating the arbitration process:

'5. Where, a) under paragraph 1, a person has presented a case to the competent authority of a Contracting State on the basis that the actions of one or both of the Contracting States have resulted in taxation of said person that is not in accordance with the provisions of this Convention, and b) the competent authorities are unable to reach an agreement to resolve that case pursuant to paragraph 2 within two years from the presentation of the case to the competent authority of the other Contracting State, any unresolved issues arising from the case shall be submitted to arbitration if the person so requests. These unresolved issues shall not, however, be submitted to arbitration if a decision on these issues has already been rendered by a court or administrative tribunal of either State. Unless a person directly affected by the case does not accept the mutual agreement that implements the arbitration decision, that decision shall be binding on both Contracting States and shall be implemented notwithstanding any time limits in the domestic laws of these States. The competent authorities of the Contracting States shall by mutual agreement settle the mode of application of this paragraph.

[Text of the footnote, which would appear on the same page:

'1. In some States, national law, policy or administrative considerations may not allow or justify the type of dispute resolution envisaged under this paragraph. In addition, some States may only wish to include this paragraph in treaties with certain States. For these reasons, the paragraph should only be included in the Convention where each State concludes that it would be appropriate to do so, based on the factors described in paragraph 47 of the Commentary on the paragraph. As mentioned in paragraph 54 of the Commentary, however, other States may be able to agree to remove from the paragraph the condition that issues may not be submitted to arbitration if a decision on these issues has already been rendered by one of their courts or administrative tribunals.'

In addition, the 2007 OECD Report also contains a revised version of the Commentary on the new paragraph of Art. 25 of the OECD MC, due to the fact that other consequential changes to the Commentary will be made when the following paragraphs are included in the OECD MC. This revised version of the Commentary consists of replacing paras. 45 to 48 and the heading preceding them with a new heading, and paras. 45 to 69 ; and to renumber existing paras. 49 to 54 as paras. 70 to 75 .

Finally, the 2007 OECD Report introduces an Annex to be added to the Commentary as a sample form of agreement that the competent authorities may use as a basis for a mutual agreement to implement the arbitration process provided for in para. 5 of Art. 25 of the OECD MC. Needless to say, competent authorities are free to modify, add or delete any provisions of this sample agreement when concluding their bilateral agreement.

\section{The absence of regulation of the mutual agreement procedure in Spain for resolving international tax disputes}

In contrast to other countries whose domestic law regulates the development of the mutual agreement procedure, the Spanish tax law does not contemplate any rule in this sense as of the present time. For instance, the United States, Canada, France, Japan, Sweden and the United Kingdom ${ }^{10}$ have enacted specific regulations regarding this issue that, together with those established in tax treaties, detail the proceedings to be observed in the development of this mechanism. It should be noted, however, that most of these internal regulations are exclusively referred to the mutual agreement procedure envisaged in Art. 25(1) of the OECD MC, that is to say, to the mutual agreement procedure in the narrower sense, but not to the other types of this procedure set out in Art. 25(3). In fact, these procedural rules were published as a result of the OECD Report on the mutual agreement procedure of 1984 (paras. 108 and 116) and para. 30 of the OECD Commentaries to this Article.

In France, the conclusion of a tax treaty is linked to the publication of an instruction ${ }^{11}$ concerning the provisions applicable to mutual agreement procedure. This instruction also designates the conditions under

\section{Notes}

10 These regulations have been published by the Inland Revenue of the United Kingdom, and have been followed by some others on the application of the arbitral method settled in the Arbitration Convention 90/436/EEC on the elimination of double taxation in connection with the adjustment of profits between associated enterprises. See 'UK guidance on using Arbitration Convention' in International Tax Report, December 1997, pp. 6-7.

11 See, for instance, Instruction 14-F-1-86 of 4 March 1986, published in Bulletin Officiel de la Direction Générale des impost 1986, no. 37, p. 1, and reproduced in Feuillet rapide Fiscal Social Francis Lefébvre 1986, no. 17, p. 31; 'France. Mutual agreement procedure (French tax authorities give information regarding the application of the mutual agreement procedure under French tax treaties)', European Taxation 1986, vol. 26, no. 5, pp. 153-156. 
which such procedure is possible and lays down the scope of application. Japan has a special law for the implementation of all double tax treaties, including provisions regarding mutual agreement procedure, and Canada has published several information circulars on the application of the procedure. ${ }^{12}$ Special directives with the force of law are published in Sweden as each new double tax treaty is enacted. These directives incorporate both general instructions and explanatory notes on specific articles of the treaty.

It can be quoted, nevertheless, that the United States has the most extensive special directives, treating the procedure in detail, setting forth the procedural rules to be followed by taxpayers to invoke competent authority negotiations and comprising an extensive catalogue of the rights and duties of both taxpayers and competent revenue authorities. ${ }^{13}$

Taking into consideration the necessity of such procedural rules, pointed out by some scholars in the Spanish tax literature ${ }^{14}$ and the recommendation of the OECD Committee on Fiscal Affairs to the Member States in order to formulate and publicize domestic rules, guidelines and procedures concerning the use of the mutual agreement procedure, the Act 36/2006 of 29 November ${ }^{15}$ was published, whose First Additional Provision (Disposición Adicional Primera) refers to the mutual agreement procedure. This Act will be developed in the near future by a Royal Decree, where the development of the mutual agreement procedure will be extensively detailed. Our discussion will be focused on the Spanish Draft of this Royal Decree.

\section{The structure of the new Spanish Draft Royal Decree on the development of the mutual agreement procedure}

\section{A. Mutual agreement procedure in the context of double tax treaties signed by Spain}

Taking both the deficiencies of the mutual agreement procedure and the convenience of the existence of domestic procedural rules on this mechanism as a starting point, the mentioned Spanish Draft attempts to provide a feasible solution in the form of regulation of the mutual agreement procedure and introduces a new advisory commission whose decision will be binding in case the mutual agreement procedure had failed, provided that certain conditions are met.

The first Title (Título I) of this Draft contains general provisions applicable to the mutual agreement procedure in the ambit of tax treaties concluded by Spain and to the mutual agreement procedure settled in the Convention 90/436/EEC on the elimination of double taxation in connection with the adjustment of profits between associated enterprises (European Arbitration Convention), such as the designation of the competent authority (Dirección General de Tributos) or the participation of the taxpayer in the procedure. As a general rule, the mutual agreement procedures regulated in this Draft are initiated at the request of the taxpayer. Notwithstanding, the procedure is completely developed by the competent authorities of the Contracting States, who also decide the solution of the international controversy.

In this sense, the taxpayer is not obliged to waive the domestic remedies in order to invoke the mutual agreement procedure, inasmuch as this procedure is supplementary to the internal one, that is to say, it only operates as long as it is contemplated in the respective convention.

The second Title (Titulo II) focuses on the regulation of the mutual agreement procedure envisaged in double tax treaties signed by Spain. Most of these treaties observe the rules established in Art. 25 of the OECD MC. In particular, this Title refers to the mutual agreement procedure provided in Art. (1) and (2) of the OECD MC, which is initiated at the request of the taxpayer as a consequence of taxation not in accordance with the provisions of the convention. The rules laid down on this matter differ depending on the initiation of the procedure in Spain or in the other Contracting State, and also taking into account which tax administration has adopted the measure that leads to double taxation.

Concerning the regulation provided when the mutual agreement procedure is conducted before the Spanish tax authorities as a result of actions adopted by the Spanish tax administration that are not in accord with the convention, Section I indicates that to be able to set the procedure in motion, the taxpayer must be a resident ${ }^{16}$ in Spain who consider that taxation charged or will be charged against him disregards the provisions of the treaty. The objections must be presented to the Spanish competent authority by the end of the period indicated in the tax treaty in

\section{Notes}

12 See, for instance Revenue Canada Information Circular no. 71-17R3, of 22 February 1991.

13 See, for instance, Revenue Procedure 91-23, IRB 1991-11, 18 (modified by Revenue Procedure 91-26, IRB 1991-17, 7), published on 19 March 1991 (a Revenue Procedure is a procedural directive issued by the Internal Revenue Service of the United States).

14 A. Ribes Ribes, 'Convenios para evitar la doble imposición internacional: interpretación, procedimiento amistoso y arbitraje’ (EDERSA, Madrid, 2003 ), p. 397.

15 Ley 36/2006, de 29 de noviembre, de Medidas para la prevención del fraude fiscal.

16 The requirement laid on the taxpayer to present his case to the competent authority of the state of which he is a resident is of general application, except in the case where a person who is a national of one state but a resident of the other complains of having been subjected in that other state to an action which is discriminatory under Art. 24.1 of the Treaty. It appears more appropriate for obvious reasons to allow him, as it is said in the Commentary to Art. 25 of the OECD MC, to present his objection to the competent authority of the Contracting State of which he is a national. In this line, it is to the same competent authority that an objection has to be presented by a person who, while not being a resident of a Contracting State, is a national of a Contracting State, and whose case comes under para. 1 of Art. 14 of the Treaty. 
question, as the date of the first notification of the action which gives rise to taxation that is not in accordance with the convention.

With regard to the procedure itself, it is convenient to consider the two distinct stages into which it is divided. The first stage, which opens with the presentation of the taxpayer's objections, takes place both at the level of dealings between him and the competent authorities of his state of residence and at the level of dealings between states. By virtue of Art. 6 of the Spanish Royal Decree, the request for the mutual agreement procedure to be initiated shall be made in writing and shall contain the information specified in this regulation to identify the case. ${ }^{17}$

If the competent authority recognizes that the complaint is justified and considers that the taxation complained of is due wholly or in part to a measure taken by the Spanish tax administration, it must give the complainant satisfaction as speedily as seems to be justified. In this situation, the problem can be resolved without resort to the mutual agreement procedure. If, however, the taxation complained of is due wholly or in part to a measure taken in the other state, the Spanish tax authorities shall set in motion the mutual agreement procedure by approaching the other Contracting State. In accordance with Art. 8.3 of the Spanish Royal Decree, the Spanish tax authorities shall provide the competent authority of the other Contracting State with the relevant information in order to resolve the issue.

Once notified of a case, the competent authorities shall discuss and negotiate but, as far as reaching mutual agreement through the procedure is concerned, they are duty bound merely to use their best efforts and not to achieve a result.

Whilst the time taken to complete a mutual agreement procedure case may vary according to its complexity, the Spanish Royal Decree sets forth a period of four months from the date of acceptance of the taxpayer's mutual agreement procedure request for the Spanish tax authority to provide an initial position paper. As it is stated in Art. 9 of the Spanish Royal Decree, the competent authorities shall exchange the responses in order to facilitate a timely resolution but no other time limits to complete the case are envisaged in the Spanish regulation analysed.

On the contrary, the Spanish Royal Decree refers solely to the request of the taxpayer for submission of the unresolved issues to an advisory commission, provided that the latter is included in the tax treaty as a supplementary dispute resolution mechanism. According to Art. 10 of the Spanish Royal Decree, the decision of the advisory commission shall be binding on the competent authorities, who shall resolve the case taking said decision into consideration.

When the competent authorities resolve the case, this resolution shall be confirmed by an exchange of letters, by virtue of Art. 14 of the Spanish Royal Decree. In addition, competent authorities shall communicate the terms of the resolution to the taxpayer as soon as possible. If the conditions of the resolution are not satisfactory to the taxpayer, he shall be entitled to withdraw from the mutual agreement process and pursue other domestic mechanisms still available. If the terms are satisfactory, the taxpayer shall accept the mutual agreement procedure result in writing. Once the exchange of letters between competent authorities has occurred and the taxpayer has accepted the resolution, the Spanish tax authority shall implement the resolution. In this respect, the taxpayer shall ask for the implementation of the agreement within six months, and the Spanish tax administration shall give it effect in its jurisdiction through a tax assessment.

\section{B. Procedure on the application of the Convention 90/436/EEC on the elimination of double taxation in connection with the adjustment of profits between associated enterprises}

As it is known, the European Arbitration Convention establishes a procedure to resolve disputes where double taxation occurs between enterprises of different Member States resulting from an upward adjustment of profits of an enterprise in one Member State. Additionally, it provides for mandatory arbitration in

\section{Notes}

7 In requesting the assistance of the competent authority, the taxpayer should provide the following relevant information:

- the name, address, and the identification number of the taxpayer;

- for transfer pricing cases, the name, address and, if possible, the taxpayer identification number of any related foreign taxpayer involved. Also the documentation described in the Spanish regulation on the Corporation tax (Royal Decree 1777/2004, of 30 July);

the name of the foreign tax administration involved;

the tax convention Article that the taxpayer asserts is not being correctly applied, and the taxpayer's interpretation of the application of the Article; the relationship, situation, or structure of the transactions, issues, or related parties involved;

a summary of the facts and an analysis of the issues for which competent authority assistance is requested;

a copy of any other relevant competent authority request and the associated documents filed, or to be filed, with the competent authority or the other Contracting State;

an indication of whether the taxpayer or a predecessor has made a prior request to the competent authority of either Contracting State on the same or related issue;

- a statement indicating whether the taxpayer has filed a notice of objections, notice of appeal, refund claim, or comparable document in either of the relevant jurisdictions;

where the request for competent authority assistance involves issues that are currently or were previously considered by the tax authorities of either Contracting State as part of an advance pricing arrangement, ruling or similar proceedings, or a statement to that effect;

if consent has not already been provided for a person to act as an authorized representative, a signed statement that a representative is authorized to act for a taxpayer in making the request; and

a copy of any settlement or agreement reached with the other jurisdiction which may affect the mutual agreement process

The request should generally be signed by the taxpayer, or by an authorized person on behalf of the taxpayer, confirming the accuracy and completeness of the facts and information presented in the request. 
cases where Member States cannot reach mutual agreement on the elimination of double taxation within two years of the date on which the case was first submitted to one of the competent authorities of the Member States involved.

The third Title (Titulo III) of the Spanish Royal Decree mentioned above sets out procedural rules in order to improve the functioning of the mutual agreement procedure in these cases, either where the procedure is initiated before the Spanish competent authorities as a result of actions of the Spanish tax administration or of the other Contracting State, and also where the procedure is conducted by the tax administration of the other state as a consequence of actions adopted by Spain or by its tax administration.

According to Art. 21 of the Spanish Royal Decree, these procedural rules shall be applied when an enterprise considers that, in any case where the European Arbitration Convention is applicable, the principles established in Art. 4 have not been observed. It should be noted, nevertheless, that this procedure shall not be initiated if actions giving rise to an adjustment of transfers of profits of the enterprises concerned resulted in a serious penalty. In this respect, where judicial or administrative proceedings are initiated with a view to a ruling that by actions giving rise to an adjustment of profits under Art. 4, one of the enterprises concerned was liable to a serious penalty, the competent authorities may stay the mutual agreement procedure until the judicial or administrative proceedings have been concluded. The taxpayer is obliged to communicate to the competent authority within one month, both the recourse to the domestic remedy and, afterwards, the resolution of the internal procedure, on the day following the presentation of the recourse or the notification of the decision, respectively.

Regarding the procedure initiated before the Spanish tax authorities as a result of actions of the Spanish tax administration, Art. 6 of the Spanish Royal Decree establishes that the case must be presented within three years of the notification of the action that results or is likely to result in double taxation within the meaning of Art. 1 of the European Arbitration Convention. Taking into account the Proposal of the European Commission for a Code of Conduct ${ }^{18}$ (Code of Conduct) for the effective implementation of the European Arbitration Convention, the date of the "first tax assessment notice or equivalent, which results or is likely to result in double taxation within the meaning of Article 1, e.g., due to a transfer pricing adjustment', is considered as the starting point for the three-year period, as it is also envisaged in the Spanish Royal Decree.

Moreover, as far as transfer pricing cases are concerned, the Code of Conduct recommends Member
States to apply this definition also to the determination of the three-year period as provided for in Art. 25(1) of the OECD MC and implemented in the double tax treaties between European Member States.

According to Art. 25 of the Spanish Royal Decree (in connection with Art. 6.1.c), a case will be regarded as having been submitted when the taxpayer provides the following documentation:

(a) identification (such as name, address, tax identification number) of the enterprise of the Contracting State that presents its request and of the other parties to the relevant transactions;

(b) details of the relevant facts and circumstances of the case;

(c) identification of the tax periods concerned;

(d) copies of the tax assessment notices, tax audit report or equivalent leading to the alleged double taxation;

(e) details of any appeals and litigation procedures initiated by the enterprise or the other parties to the relevant transactions and any court decisions concerning the case;

(f) an explanation by the enterprise of why it thinks that the principles set out in Art. 4 of the European Arbitration Convention have not been observed;

(g) an undertaking that the enterprise shall respond as completely and quickly as possible to all reasonable and appropriate requests made by a competent authority and have documentation at the disposal of the competent authorities; and

(h) any specific additional information requested by the competent authority within two months upon receipt of the taxpayer's request.

If the competent authority believes that the enterprise has not submitted the minimum information necessary for the initiation of a mutual agreement procedure, it will invite the enterprise within two months upon receipt of the request to provide it with the specific additional information it needs.

If the complaint appears to be well founded and the Spanish competent authority is itself able to reach a satisfactory solution, the case resolution shall be attempted as quickly as possible, having regard to the complexity of the issues in the particular case. If, on the contrary, the Spanish competent authority is not able to arrive at a solution, the case resolution shall be attempted through mutual agreement with the competent authority of the other Contracting State concerned within a period of two years of the date on which the case was first submitted to the mutual agreement procedure. At the same time, the Spanish competent authority will inform the person invoking the European Arbitration Convention that it has initiated the mutual agreement procedure.

As it is stated in Art. 26(2) of the Spanish Royal

18 Communication from the Commission to the Council, the European Parliament and the European Economic and Social Committee on the work of the EU Joint Transfer Pricing Forum in the field of business taxation from October 2002 to December 2003, and on a proposal for a Code of Conduct for the effective implementation of the Arbitration Convention (90/436/EEC of 23 July 1990). 
Decree, if the competent authorities fail to reach an agreement that eliminates the double taxation within that period, they shall set up an advisory commission charged with delivering its opinion on the elimination of the double taxation in question.

With regard to the deadline for submitting the case to the advisory commission, the two-year period starts, by virtue of Art. 27 of the Spanish Royal Decree, on the latest of the following dates: (a) the date of the tax assessment notice; or (b) the date on which the competent authority receives the request and the documentation required. Notwithstanding, in case that enterprises had tried the remedies available under the domestic law of the Contracting States, the term of two years referred to shall be computed from the date on which the judgment of the final court of appeal was given.

On the other hand, Art. 28 of the Spanish Royal Decree refers to the position paper ${ }^{19}$ that the Spanish competent authorities shall send to the other Contracting State. The position paper will be sent to the competent authorities of the other Contracting State no later than four months from the latest of the following dates: (a) the date of the tax assessment notice; or (b) the date on which the competent authority receives the request. Spanish regulation does not include any other procedural rule concerning time limits or the response to be taken by the other Contracting State as the regulation of these practical arrangements shall be made under the domestic law of the other Contracting State. ${ }^{20}$

As stated above, if the competent authorities fail to reach an agreement within the period of two years previously referred to, they shall set up an advisory commission charged with delivering its opinion on the elimination of the double taxation, not more than six months from the date on which the matter was referred to it. Even though Art. 11.2 of the European Arbitration Convention allows the competent authorities concerned to agree on additional rules of procedure, the Spanish regulation refers to Arts. 9 and 10 of the European Arbitration Convention as the general rules on the functioning of the advisory commission.

On the other hand, according to Art. 31(1) and (2) of the Spanish Royal Decree, the competent authorities party to the procedure shall take a decision which will eliminate the double taxation within six months of the date on which the advisory commission would have delivered its opinion. The competent authorities may take a decision that deviates from the advisory commission's opinion. It is important to note that, different from the wording of the Spanish regulation, Art. 12.1 of the Code of Conduct states that in case the competent authorities fail to reach an agreement, they shall be obliged to act in accordance with that opinion.

Finally, Art. 31(3) of the Spanish Royal Decree sets out that the decision taken by the Contracting States shall prevent recourse by the taxpayers affected, who will be able to appeal otherwise the administrative actions that will be enacted in order to apply that decision.

The fourth Title (Titulo IV) of the Spanish Royal Decree focuses on the regulation of the necessary measures to ensure that the suspension of tax collection during cross-border dispute resolution procedures under the European Arbitration Convention can be obtained by enterprises engaged in such procedures, under the same conditions as those engaged in a domestic appeals/litigation procedure. As noted in the Code of Conduct, it would be convenient for Member States to extend these measures to the cross-border dispute resolution procedures under double tax treaties between Member States.

\section{Proposed amendments to the Spanish Draft for the improvement of the mutual agreement procedure}

Obviously, the Spanish Draft Royal Decree on the development of the mutual agreement procedures concerning direct taxation deserves, from our point of view, a positive critique as it is aimed at clarifying the internal phase of these procedures by setting out a useful guidance to be observed by the Spanish competent authorities involved in the case. In this line, it should be emphasized that the Spanish regulation reflects both the procedural rules envisaged in the MEMAP and in the European Arbitration Convention (and the Code of Conduct) respectively, and it is intended to increase the certainty of the taxpayers in this field. For that reason, the domestic rules do not introduce new aspects of special relevance to be commented on, apart from some issues that we would like to highlight for the improvement of the Draft regulation.

\section{Notes}

19 In this sense, the Code of Conduct details the content of this paper that shall set out: (a) the case made by the person making the request; (b) its view of the merits of the case, e.g., why it believes that double taxation convention has occurred or is likely to occur; and (c) how the case might be resolved with a view to eliminate double taxation together with a full explanation of the proposal. The position paper will contain a full justification of the assessment or adjustment and will be accompanied by basic documentation supporting the competent authority's position and a list of all other documents used for the adjustment.

20 This aspect is regulated by the Code of Conduct that recommends the competent authority of the other Contracting State involved to respond as quickly as possible, and no later than six months after receipt of the position paper. Furthermore, it is detailed that the response should take one of the following two forms: (a) if the competent authority believes that double taxation has occurred, or is likely to occur, and agrees with the remedy proposed in the position paper, it will inform the other competent authority accordingly and make such adjustments or allow such relief as quickly as possible; (b) if the competent authority does not believe that double taxation has occurred, or is likely to occur, or does not agree with the remedy proposed in the position paper, it will send a responding position paper to the other competent authority setting out its reasons and proposing a time limit for dealing with the case, taking into account its complexity. The proposal will include, whenever appropriate, a date for a face-to face meeting, which should take place no later than 18 months from the latest of the following dates: (a) the date of the tax assessment notice; or (b) the date on which the competent authority receives the request and the minimum information. 
The first aspect we would like to raise is the entitlement of the taxpayer in order to set the mutual agreement procedure in motion. The Spanish regulation (Art. 4) does not determine whether the denial of this entitlement to present a request to the Spanish competent authorities could be appealed against or not to the domestic courts, even though there are some Spanish judicial decisions that attempted in favour of this judicial control, such as the decision of the National Court (Audiencia Nacional) of 14 June 1999 and the decision of the Supreme Court (Tribunal Supremo) of 15 April 2003.

Secondly, regarding the date from which the taxpayer shall present his request to initiate the mutual agreement procedure, Art. 5 of the Spanish Royal Decree refers to that presentation within the period established in the particular convention in question, computed from the day following the notification of the tax assessment or equivalent which gives rise to taxation not in accordance with the convention. From the wording of the Article, it appears as if the taxation that disregards the provisions of the convention and can be complained of by the taxpayer is solely a tax administrative assessment. In our opinion, the solution adopted is not correct, inasmuch as the action that is not in accord with the provisions of the convention can be taken previously to the tax assessment, ${ }^{21}$ e.g. through a tax examination. ${ }^{22}$

On the other hand, according to Art. 11(2) of the Spanish Royal Decree, ${ }^{23}$ the taxpayer is not allowed to appeal the final decision of the internal phase of the mutual agreement procedure, but rather the actions of the Spanish tax administration in order to apply said decision. From our perspective, the agreement reached by the competent authorities of the Contracting States constitutes an administrative action, which should be submitted to the domestic judicial control in case of violation or abuse of the treaty in question. ${ }^{24}$ This remark is also applicable to the solution adopted under Art. 31(3) of the Spanish Royal Decree, regarding the procedure on the application of the European Arbitration Convention.

Concerning the implementation of the agreement, it should be noted that Art. 15(3) of the Spanish Royal Decree refers to the consequences of this decision derived from the mutual agreement procedure with regard to the previous tax assessment made by the Spanish tax administration. Moreover, in our view, the situation where the agreement to avoid the double taxation leads to a taxpayer's right to claim the tax refund should also be detailed.

Another aspect we would like to point out is the regulation provided by Art. 18 of the Spanish Royal Decree, concerning the procedure initiated before the competent authorities of the other Contracting State. In accordance with this provision, the Spanish tax authorities shall acknowledge receipt of the documentation sent by the foreign competent authorities. In our view, this communication of the receipt should also be made to the taxpayer, and not only to the competent authorities of the other Contracting State, due to the fact that from this date is computed the period in order to submit the case to the advisory commission. ${ }^{25}$

Besides, as commented on above, Art. 27 of the Spanish Royal Decree sets out that the two-year period in order to present the controversy to the advisory commission, as far as the procedure on the application of the Convention 90/436/EEC is concerned, starts on the latest of the following dates: (a) the date of the tax assessment notice; or (b) the date on which the competent authority receives the request and the minimum information required. In contrast to this rule, it seems advisable to take into account solely the date of the tax notification because of its certainty. The taxpayer does not acknowledge the date of receipt of the request and documentation by the competent authorities, and for this reason, the latter date should not be taken in consideration. ${ }^{26}$

The uncertainty of the start of the six-month period in which the advisory commission shall deliver its opinion (as envisaged in Art. 30 of the Spanish Royal Decree) can be equally quoted. By virtue of this provision, the opinion shall be delivered not more than six months from the date on which the matter was referred to the competent authority. This rule brings about some problems of interpretation if the documentation required is not totally provided to the advisory commission, but only partially; or when it is assumed to have received the total information; or even the question of who is the competent authority to determine whether the documentation provided is complete or not. It will be desirable, from our point of view, to amend this provision by setting out a system through which the advisory commission acknowledges from the date of receipt in order to guarantee the rights of the taxpayers. ${ }^{27}$

In connection with the suspension of tax collection settled in Art. 38 of the Spanish Royal Decree, there is

\section{Notes}

21 Asociación Española de Asesores Fiscales, 'Notas de la AEDAF al proyecto de Real Decreto por el que se desarrolla la Ley 36/2006, de 29 de noviembre, de medidas para la prevención del fraude fiscal', Revista Técnica Tributaria 2007, no. 78, pp. 172-173.

22 See, in this respect: Decision of the Spanish National Court (Audiencia Nacional) of 14 June 1999.

23 This provision is also stated by the First Additional Provision (Disposición Adicional Primera), para. 4, of the Spanish Act 36/2006, previously mentioned.

24 J.M. Farré Español, 'La doble imposición. Modelo OCDE 1992' (Ed. Einia, Barcelona, 1994), p. 306; A. Ribes Ribes, see n. 14 above, p. 401. Against this position: R. Palacín Sotillos, 'El procedimiento amistoso y el arbitraje como instrumentos para evitar la doble imposición internacional', in T. Cordón Ezquerro (Dir.), Manual de Fiscalidad Internacional, 2nd edn (Instituto de Estudios Fiscales, Madrid, 2004), p. 1095.

25 Asociación Española de Asesores Fiscales, see n. 21 above, p. 174.

26 Ibid., p. 175

27 Ibid., p.175. 
no obligation for the competent authority to deliver a specific decision, where the suspension of tax collection requested by the taxpayer is denied. This solution is not in accord with Art. 40 of the Spanish Royal Decree, under which the notification of whatever decision on the suspension of tax collection is stated, as a general rule. ${ }^{28}$

Finally, we would like to focus on Art. 39(1) and (3) of the Spanish Royal Decree, which also establishes practical rules in order to suspend tax collection. Concerning the interest charges to be imposed in these cases, it is important not to lose sight of the principles introduced by the Spanish General Tax Act, ${ }^{29}$ according to which there shall not be applied interests where the tax administration exceeds the period to resolve the case. Taking this premise into account, there should not be imposed interests on the taxpayer and the six months conferred to the resolution of the case. Likewise, another addition should be made to Art. 39(3) of the Spanish Royal Decree regarding the possibility of the taxpayer to designate guarantees different from the one previously offered, where said guarantees concern the suspension of tax collection debts to be executed by the tax administration.

\section{Notes}

28 Ibid., p. 175 .

29 Ley 58/2003, de 17 de diciembre, General Tributaria. 